\title{
Analysis of Zero Percent Down Payment Mortgage Policy as an Efforts to Accelerate Economic Recovery in Pandemic Times
}

\author{
Gusti Ayu Ketut Rencana Sari Dewi ${ }^{1, *}$ Ni Luh Asri Savitri ${ }^{1}$ Made Arie Wahyuni ${ }^{1}$ \\ ${ }^{1}$ Department of Economics and Accounting, Universitas Pendidikan Ganesha, Singaraja, Indonesia \\ *Corresponding author. Email: ayurencana@gmail.com
}

\begin{abstract}
The impact of the Covid-19 pandemic on the national and global economy was felt in the second quarter of 2020. In the first quarter of 2020, the national economy still grew by $2.97 \%$, although it was down compared to the first quarter of 2019 which was 5.07. This is due to the external influence of Covid-19 which has spread in several countries such as China. In the second quarter, although there is no official data yet, Indonesia is estimated to experience a contraction (negative economic growth) of around 3\%. This happened because the social distancing policy or LargeScale Social Restrictions (PSBB) only started in mid-March. Social distancing and PSBB greatly affect economic activity. Economic observers and International Institutions (IMF, World Bank, OECD) stated that there was a world economic recession in 2020. One of the drivers of the national economy is domestic consumption, the more consumption the economy will move. Bank Indonesia (BI) extended slack on property loans in February 2021 to accelerate economic recovery during the pandemic. In addition to lowering the benchmark interest rate, BI has also set Loan to Value (LTV) and Financing to Value (FTV) at $100 \%$ for property loans. This policy is effective March 1, 2021 until December 31, 2021. PT Bank Rakyat Indonesia (Persero) Tbk. is one of the banks that meet the requirements to provide 0\% DP mortgages to its customers. PT. Bank Rakyat Indonesia (Persero) Tbk. to be one of the few banks in the world that consistently provides the best service to the micro, small and medium enterprises (MSME) segments to support the improvement of the community's economy. PT. Bank Rakyat Indonesia (Persero) Tbk. welcomes the relaxation policy of easing the LTV/FTV ratio for property loans and indent housing loans (KPR), as well as easing down payments for motor vehicle loans. PT. Bank Rakyat Indonesia (Persero) Tbk. which has a long history as a bank that has served the Indonesian community on a small scale economy, always prioritizing services to the micro, small and medium enterprise (MSME) segment. PT Bank Rakyat Indonesia Tbk (BBRI) is optimistic that the distribution of Home Ownership Loans (KPR) will stretch. The purpose of this study was to study specifically at PT Bank Rakyat Indonesia (Persero) Tbk. The Singaraja Branch Office which is related to efforts to increase the distribution of housing loans to the 0 Percent DP KPR leeway policy. So that in this research the type of research used is descriptive research with a case study approach.
\end{abstract}

Keywords: Mortgage policy, 0 percent down payment, Credit.

\section{INTRODUCTION}

The impact of the Covid-19 pandemic on the national and global economy was felt in the second quarter of 2020. In the first quarter of 2020, the national economy still grew by $2.97 \%$, although it was down compared to the first quarter of 2019 which was 5.07. This is due to the external influence of Covid-19 which has spread in several countries such as China. In the second quarter, although there is no official data yet, Indonesia is estimated to experience a contraction (negative economic growth) of around 3\%. This happened because the social distancing policy or Large-
Scale Social Restrictions (PSBB) only started in midMarch. Social distancing and PSBB greatly affect economic activity. Indonesia's economic situation is still better at the regional and world levels. Several countries experienced very deep contractions, for example Singapore by $41.2 \%$, the United States estimated at around $10 \%$, and the UK by around $15 \%$. Meanwhile, the World Bank has predicted that the global economy in 2020 will contract by $5.2 \%$ and Indonesia by $0.3 \%$, which is the second best economic country after Vietnam, which is estimated to have positive economic growth. 
Economic observers and International Institutions [1] stated that there was a world economic recession in 2020. The recession was experienced deeper by developed countries. Indonesia is experiencing a recession but a mild recession because the economic contraction is estimated to be "only" around -3\%-0\% and will not last long, around 2 quarters. This prediction certainly makes us more optimistic to implement national economic recovery policies consistently and build cooperation from all components of the nation. The Central Government takes a holistic economic recovery policy. The implementation of these policies must be supported by local governments. Local governments have a strategic role in encouraging the acceleration and effectiveness of national economic recovery. The local government understands the regional economic structure, demography, and socioeconomic conditions of its people. In addition, APBD policies can be synergized to encourage the acceleration of economic recovery in the regions. In addition, the community and business actors, including MSMEs, also have a strategic role in accelerating Indonesia's economic recovery. The government provides fiscal and monetary facilities/stimulus, which should be welcomed positively by business actors by moving their business well. National economic recovery is carried out by adopting comprehensive fiscal and monetary policies. In addition, the Government also allocates APBN funds for economic recovery amounting to Rp. 695.2 trillion. It is hoped that the national economic recovery will begin to be felt in the third quarter. Although it does not grow positively, it is hoped that the national economy will not contract as much as the second quarter. [2] explained, in the fourth quarter, it is hoped that the national economy will grow positively so that the contraction in 2020 can be suppressed as little as possible. Meanwhile, in 2021, it is hoped that the national economy will experience a significant recovery,

To achieve the above objectives, there are 3 (three) policies carried out, namely increasing domestic consumption, increasing business activity and maintaining economic stability and monetary expansion. These policies are implemented simultaneously with synergy between fiscal policy holders, monetary policy holders and related institutions. One of the drivers of the national economy is domestic consumption, the more consumption the economy will move [3]. In order to support the national economic recovery, Bank Indonesia maintains the stabilization of the Rupiah exchange rate, lowers interest rates, purchases Government Securities, and maintains macroeconomic and financial system stability. Bank Indonesia (BI) has decided to relax the Loan to Value/financing to value (LTV/FTV) ratio for property loans/financing to a maximum of 100 percent. In other words, consumers can get a home ownership loan (KPR) with a down payment (DP) of 0 percent. Bank Indonesia made adjustments to the Loan to Value
(LTV) Ratio for Property Loans, Financing to Value (FTV) Ratio for Property Financing, and Down Payments for Motor Vehicle Loans or Financing through the issuance of Bank Indonesia Regulation Number 21/13/PBI/2019 concerning Amendments to Bank Indonesia Regulation Number 20/8/PBI/2018 concerning Loan to Value Ratio for Property Loans, Financing to Value Ratio for Property Financing, and Advances for Motor Vehicle Loans or Financing (PBI LTV/FTV and Advances). Along with the birth of this macroprudential policy mix, the central bank determined several requirements. A down payment of 0 percent for houses can only be given by banks with a non-performing loan ratio (NPL/NPF) below 5 percent, with the obligation to pay attention to the principle of prudence.

This LTV/FTV relaxation at a maximum of 100 percent applies to landed houses, flats, and shop houses/rukans, whether based on murabahah contracts, istishna contracts, MMQ contracts, and IMBT contracts. Landed houses that receive a DP allowance of 0 percent are landed houses with dimensions of less than 21 square meters, between 21 square meters to 70 square meters, and more than 70 square meters. The 100 percent LTV/FTV provisions for landed houses, flats, and shophouses/shophouses also apply to environmentally friendly properties. This LTV/FTV allowance also applies to banks with a high nonperforming loan/financing ratio above 5 percent. The purchase of landed houses and the first house for type 21 at a bank with a high NPL/NPF still gets a maximum allowance of 100 percent. However, this does not apply to other types of properties. The allowance for other types of property only reaches 90-95 percent. For landed houses and the first type 70 flat based on a murabahah contract, istishna contract, MMQ contract, or IMBT contract, for example, they get 95 percent leeway. As for the second and third landed houses and flats based on the four contracts, 90 percent of the allowance is granted. As for landed houses with dimensions of 21 square meters to 70 square meters, 95 percent of the allowance is granted. While the second and third landed houses and flats for type 21 get 95 percent leeway.

Not only that, the central bank also removed the provision for gradual disbursement of pivot properties to encourage credit growth in the property sector, while still paying attention to the principles of prudence and risk management. [4] explained, these policies are all part of the Integrated Policy Package of the Financial System Stability Committee (KSSK) for Increasing Business Financing in the context of Accelerating Economic Recovery (PEN),. The policy is aimed at carefully strengthening economic policies to support a faster recovery. PT Bank Rakyat Indonesia (Persero) Tbk. is one of the banks that meet the requirements to provide 0\% DP mortgages to its customers. PT. Bank 
Rakyat Indonesia (Persero) Tbk. to be one of the few banks in the world that consistently provides the best service to the micro, small and medium enterprises (MSME) segments to support the improvement of the community's economy. PT. Bank Rakyat Indonesia (Persero) Tbk. welcomes the relaxation policy of easing the LTV/FTV ratio for property loans and indent housing loans (KPR), as well as easing down payments for motor vehicle loans. PT. Bank Rakyat Indonesia (Persero) Tbk. which has a long history as a bank that has served the Indonesian community on a small scale economy, always prioritizing services to the micro, small and medium enterprise (MSME) segment. PT Bank Rakyat Indonesia Tbk (BBRI) is optimistic that the distribution of Home Ownership Loans (KPR) will stretch.

In 2020, this state-owned bank still managed to record mortgage growth amid the pressure of the Covid19 pandemic. Throughout 2020, BRI managed to record mortgage disbursements growing by $10.9 \%$ year on year (yoy). The increase in BRI's mortgage distribution was much higher than the industry average. The existing relaxation will certainly help encourage public consumption of property which can be a factor driving demand for bank credit, especially consumer credit. Meanwhile, BRI's consumer loan growth as of the end of 2020 still rose $2.3 \%$ to Rp143.7 trillion with a nonperforming loan ratio at $1.49 \%$. A relatively good increase occurred in KPR, which rose $10.6 \%$ to Rp. 35.7 trillion, while $\mathrm{KKB}$ was cut by $26.8 \%$ to Rp. 3 trillion. In 2021, the Company is aiming for a mortgage growth of around $15 \%-17 \%$. Of course, this target is in line with the policy of relaxing the LTV/FTV ratio for property loans and housing loans (KPR) which will accelerate economic recovery during the pandemic.

The purpose of this study was to study specifically at PT Bank Rakyat Indonesia (Persero) Tbk. The Singaraja Branch Office which is related to efforts to increase the distribution of housing loans to the 0 Percent DP KPR leeway policy. So that in this research the type of research used is descriptive research with a case study approach.

The formulation of the problem in this study is as follows: a). How is the Flow Chart Analysis of the 0 Percent DP KPR Policy Implementation at PT. BRI Tbk Singaraja Branch Office? b). How is the Financial Ratio Analysis of Mortgage Distribution at PT. BRI Tbk Singaraja Branch Office? c). How the Impact of 0 Percent DP Mortgage Policy on the Performance of PT. BRI Tbk Singaraja Branch Office?

\section{LITERATURE REVIEW}

\subsection{House Ownership Credit}

Home Ownership Loans (KPR) are financing products or loans given to home buyers with a financing scheme of up to a certain percentage of the price of the house or property (Kasmir. 2014). Until now, mortgages in Indonesia are still provided by banks, although there are already several finance companies (leasing) that also channel financing from secondary housing finance institutions. With a mortgage, the community does not have to provide funds in the amount of the price of the house, but it is enough to provide funds equal to the down payment and the rest can be paid in monthly installments during the term of the mortgage.

Home purchases are made by the seller as the owner of the house with the buyer as the person who will buy the house, Soza and Suryani (2020). After the price is agreed upon, the buyer submits an amount of money according to the price and both parties sign the deed of sale and purchase. The role of banks in the buying and selling process occurs if the buyer has not been able to meet the funds according to the selling price.

\subsection{Loan to Value Ratio}

Financial ratios are always an indicator of the success of an industry in managing its finances. This ratio is very important especially for banks, which are financial institutions. As part of the financial ratios, banks have a loan-to-value (LTV) ratio. This LTV ratio compares the ability of banks to provide credit loans to customers for home ownership. Therefore, the LTV ratio is closely related to anything related to housing.

History of Basic Calculations and Constantly Changing Maximum Limits of LTV Ratio. Bank Indonesia (BI) as the central bank throughout Indonesia provides requirements regarding a reasonable LTV ratio for each bank. The LTV ratio figures are compared with each type of house offered by each bank. In general, as per regulation No. 17/PBI/2015 concerning the LTV ratio, there are 3 tiers of BI policy regarding LTV, which are named LTV I, II, and III, respectively.

Each LTV I policy is based on BI Circular (SE) No. 14/10/DPNP as of March 15, 2012 and SE BI No. $14 / 33 / \mathrm{DPbS}$ as of 27 November 2012, where in this LTV policy, BI sets a maximum figure of $70 \%$ for the LTV ratio as the ratio of conventional and sharia home loan financing, unless the loan is a program from the Indonesian government.

In the LTV II policy formulated in SE BI No. 15/40/DKMP as of September 23, 2013, the basic considerations for the LTV ratio are determined by the purpose of the loan and the type of mortgaged house. In general, the maximum number of LTV II policies ranges from $50 \%$ to $90 \%$ depending on the purpose of the home loan and the type of house (starting from shop houses/rukans to houses of type over type 70 ). Then, the 
LTV III policy as formulated in PBI No. 17 of 2015 is an improvement from the previous LTV II policy. In this improvement, houses that are used as collateral are more specifically categorized according to their type (site, flat, or shop/house shop), type of house (between types 21-70), and the purpose of financing (starting from MMQ, IMBT, to murabahah). This is also where the maximum limit for the LTV ratio increases compared to the previous tier, which is $65 \%$ to $90 \%$. BI always tries to update the policy regarding the calculation basis and the maximum LTV limit. These policy reform efforts are generally based on supervision of housing-related financing, so that any financial problems involving the property sector can be resolved in an orderly manner.

Basis for Changes in LTV Ratio Based on Economic Conditions

The LTV ratio is a ratio that involves the strength of the bank in providing loans with matters relating to housing. In fact, the real LTV ratio for all banks is always changing, depending on changes in interest rates and the value of the house that is used as collateral. Because the BI interest rate (BI rate) is the basis for the interest rates of other banks, the LTV rate may increase or decrease as the BI rate increases or decreases. In addition, because every year there is always a new home trend, it could be that the value of a house that is "older" in its design will experience a decrease in value from the beginning when it was still "on the rise", so this also affects the LTV number.

The Impact of the Further Additional Policies Taken by BI Related to the LTV Ratio Number. Since anything related to financial matters is almost always a complicated matter, BI's policy regarding the LTV ratio also cannot stand alone without other supporting policies.

In addition to the LTV ratio, $\mathrm{BI}$ has also implemented a policy of easing down payments for housing or DP, both of which are related to housing. The policy of easing the down payment along with the increase in the maximum percentage of the LTV ratio is expected to make people more frugal in spending down payments to pay for their dream homes. The combination of the "frugal" policy between the easing of down payments and the renewal of the LTV ratio has made the Indonesian Composite Stock Price Index (CSPI) predict that property sector stocks will be more excited than in previous years.

[5] explained, Until now, the property sector is one of the sectors that people are most interested in. There's been a lot of progress both in terms of houses and developers working on them. That's all because BI has set policies that support LTV ratios that match one another, so that many people become comfortable to carry out any transactions related to property.

From the historical points of changes in BI's policy regarding the LTV ratio, we can see BI's efforts to make the property or housing sector the friendliest sector for all levels of society. In addition, the next two points regarding the basis for changes in the LTV ratio figure according to economic conditions and additional policies formulated by BI to explain how the LTV ratio, which is "only" in the form of numbers, can actually make changes in the Indonesian economy, especially in the property or housing sector.

\section{METHOD}

The type of research used in this research is descriptive research with a case study approach. [6] suggests "descriptive research is research that aims to describe a certain condition or phenomenon, not sorting out or looking for certain factors or variables", the purpose of researchers using this type of research is to study specifically an object at PT. Bank Rakyat Indonesia (Persero) Tbk Singaraja Branch Office which is related to efforts to minimize non-performing loans. So that in this research the type of research used is descriptive research with a case study approach.

\subsection{Data collection technique}

Data collection in the early stages comes from documentation studies and through focus group discussions with resource persons who have expertise in the field to explore related problems. The subject who became the source of the interview was the Head of the Branch of PT. Bank Rakyat Indonesia (Persero) Tbk Singaraja Branch Office namely Mr. Yogie Harris Nainggolan, Credit Analysis Officer, namely Mr. Atta, and the Accounting Section namely Mrs. Sri Handayani. Documentation is a means of assisting researchers in collecting data or information by means of letters, announcements, meeting minutes, written statements of certain policies and other written materials. This data collection technique is very useful because it can be done without disturbing the object or atmosphere of the research. The research location is the BRI Singaraja Branch Office, Address: Jl. Ngurah Rai No. 74, Singaraja, Telephone: (0362)23432,21980 (0362)24576.

\subsection{Data Analysis Techniques}

From the data obtained from various sources in the form of books, scientific journals, magazines, newspapers and the internet, it will be used as an important material to describe the conditions and symptoms that develop in the problems to be studied. Meanwhile, important information generated through interviews will be utilized by first grouping it according to the problem in order to find the core of the problem to make it easier to analyze.

The process of analysis in research is a very important and decisive part in achieving the research objectives that have been set. The data that has been collected is then classified, identified and interpreted using an appropriate analytical technique so that the results of the analysis will provide useful meaning and meaning to describe the phenomena that occur. 


\section{RESULTS \& DISCUSSION}

The 0 percent DP house program is a government policy to facilitate residential ownership, both houses and apartments. This is a form of relief during the pandemic in order to be able to buy a house. Bank Indonesia issued a policy of easing Loan to Value (LTV) for property loans and KKB by 100 percent effective March 1, 2021 until December 31, 2021. LTV is the total value of goods that can be paid in installments, for example, LTV $80 \%$ means $80 \%$ of the total The price of the house can be paid in installments, the remaining $20 \%$ must be paid in cash in advance, aka a down payment. If the LTV is $100 \%$, it means that the entire house price can be repaid in installments, there is no need for a down payment or down payment, aka 0 percent down payment. So far, down payment has become one of the obstacles for people to realize their dream of owning a house. BPS data shows that out of 1,078 respondents, $67 \%$ admitted to having problems with down payment. During this pandemic, people's ability to buy houses is even more affected. Mr. Yogie as the Head of the BRI Singaraja Branch said the easing of down payments from BI was aimed at encouraging credit, especially in the property sector which was also badly affected by the Covid-19 pandemic.

Implementation of 0 Percent DP Mortgage Policy at PT. BRI Tbk Singaraja Branch Office does not have special requirements for consumers or property types. The government further stipulates this $0 \%$ DP requirement for banks that become mortgage lenders. So, both houses, apartments, shop houses, or office buildings can be purchased with a $0 \%$ down payment. Meanwhile, from the consumer side, the conditions are in accordance with the general terms of the Home Ownership Credit (KPR) as follows:

Requirements for consumers in applying for a 0 Percent DP KRP include: a) Indonesian citizen 21 years old, b) Have a steady income, c) Have a healthy credit record, d) Photocopy of the applicant's ID card, e) Photocopy of Family Card (KK), f) Photocopy of Personal TIN, g) Original Salary Slip or Income Certificate, h) Work certificate (for employees), i) Photocopy of practice license (for professionals such as doctors, lawyers, etc.), j) Photocopy of Current Account, k) Photocopy of KTP of Husband or Wife (if married), 1) Copy of Marriage or Divorce Certificate (if married or divorced), m) Notary property separation deed (if any) and n) Company Recommendation Letter (recommended)

Meanwhile, the Government imposed conditions for mortgage lending banks, namely the BRI Singaraja Branch to ensure that credit quality remained good and the $0 \%$ DP housing policy did not cause the number of bad loans to increase. BRI Singaraja Branch as a bank that can provide mortgages without a down payment is a bank that meets the requirements, namely a bank with an NPL ratio of $<5 \%$ with a policy of being able to provide a down payment of $0 \%$ for all types and all consumers.
The process of applying for a mortgage without a down payment is the same as the process of applying for a mortgage in general, [7]. In the process of applying for a mortgage, the developer will usually be assisted directly by a developer who has become a partner at BRI Singaraja Branch. If you choose a mortgage that does not work with the housing developer, the management of the mortgage is done alone. Completing all the requirements as written above, BRI Singaraja Branch will approve the mortgage application within one month. Within one month, the bank as the mortgage provider will conduct a survey process on several different parties. The survey process will examine all financial activities at Bank Indonesia to determine whether the customer is registered on a credit blacklist.

According to the results of an interview with $\mathrm{Mr}$ Atta, the Credit Analyst at BRI Tbk Singaraja Branch Office, there is no property price requirement for this $0 \%$ down payment. So, regardless of the property price, as long as BRI Tbk Singaraja Branch Office is willing and qualified to provide a mortgage with a $0 \%$ down payment, customers can buy it in installments without a down payment. Installments without a down payment can be said to ease up front, but the number of installments will certainly be bigger. If the customer has money for a down payment, there is nothing wrong with buying a house with a down payment. The government also does not regulate the types of housing that can be submitted for installments without a down payment. Starting from a type smaller than $21 \mathrm{~m} 2$ to a type larger than $70 \mathrm{~m} 2$, customers can buy it in installments without a down payment. So, customers can choose any property, anywhere, and at any price with no down payment installments.

According to the Accounting Department, Mrs. Sri Handayani, home ownership loans (KPR) are considered to have managed to grow quite well after the tax exemption stimulus provided by the government and the loosening of loan to value (LTV) provided by Bank Indonesia (BI). Until the first half of 2021, property loans will support bank credit. Even the rate of mortgage loans, which is projected to grow even higher by the end of the year compared to other credit sectors, even though mortgage interest rates have not fallen significantly. PT Bank Rakyat Indonesia (Persero) Tbk, for example, stated that the driving factor for the current growth of BRI mortgage financing is the many incentives provided by the government for the property sector.

"Such as easing LTV or 0\% down payment and VAT subsidies for house purchases until August," said Mr. Yogie, Head of the BRI Singaraja Branch. Mr. Yogie said that this increase was not only supported by incentives from the government, but also by the high demand for housing and promotions from developers. "For now, BRI's mortgage interest starts from 3.88\% fixed for the first year to $7.49 \%$ fixed for the first 5 years," To encourage mortgage growth, Mr. Yogie said that BRI has a strategy by working on a more specific market. such as the state civil apparatus (ASN), TNI, and POLRI as well as conducting the KPR Virtual Expo 
event. "Besides that, BRI also joins promos with BRI partner developers. BRI's mortgage growth until June 2021 was a positive growth of $3.97 \%$ year on year (yoy). Until the end of 2021, BRI is optimistic that it will be able to increase mortgage financing to grow by $6 \%$ yoy nationally.

Based on financial reports published in the first quarter of 2021, PT Bank Rakyat Indonesia (Persero) Tbk or BRI recorded a consolidated profit of $\mathrm{Rp} 6.86$ trillion in the first quarter of 2021. Meanwhile, BRI's micro credit grew by double digits, namely $12.4 \%$ year on year (YoY). On the agenda of the BRI Financial Performance Report for the First Quarter of 2021, the first three months of 2021 BRI has disbursed loans of Rp 914.19 trillion. Credit for MSMEs dominates the amount of credit disbursement, with a portion of $\mathrm{Rp}$ 736.8 trillion. Meanwhile, the number of corporate loans amounted to Rp 177.39 trillion. BRI's MSME loan portfolio has reached $80.6 \%$. This is proof of BRI's commitment to support the performance of MSMEs during the national economic recovery.

BRI not only pursues the quantity of lending, but also maintains the quality of the credit. Mr. Yogie explained that BRI's credit quality is in good condition. This is reflected in the Non Performing Loan (NPL) value of $3.16 \%$. "In the midst of today's challenging conditions, in fact, the company is able to maintain the quality of the loans disbursed properly.

And this is reflected in the ratio of non-performing loans, called NPL, which was maintained at the level of $3.16 \%$, And then for the NPL, there was also a provision for costs for asset quality decline. BRI's reserves for NPL reached $250.6 \%$, so 2.5 times of NPL has been reserved. Meanwhile, third party funds collected by BRI during the first quarter of 2021 reached $\mathrm{Rp} 1,049.32$ trillion. The details of this amount are $\mathrm{Rp} 443.87$ trillion in savings, $\mathrm{Rp} 174.33$ trillion in current accounts and Rp. 431.12 trillion. The Head of the BRI Singaraja Branch said that in the first three months of 2021 BRI had recorded a profit of Rp 6.86 trillion. Meanwhile, BRI's assets grew positively by $3.83 \%$ YoY with a total value of Rp. 1,411.05 trillion.

"The sustainability of BRI's performance is also reflected in the LDR and CAR ratios which are at an ideal number. BRI's LDR at the end of March 2021 was $87.12 \%$, while the CAR was $19.74 \%$, an increase from the same period the previous year, which was 18.56 $\%, "$. So, it can be summarized that the 0 Percent DP Mortgage Policy is able to improve the performance of PT. BRI Tbk Singaraja Branch Office in the first quarter of 2021.

\section{CONCLUSION}

Based on the results of research and discussion that have been described in the previous chapter, the authors can draw several conclusions as follows: a) The 0 percent down payment program is a government policy to facilitate housing ownership, either houses or apartments. This is a form of relief during the pandemic in order to be able to buy a house. Bank Indonesia issued a Loan to Value (LTV) easing policy for property loans and KKB by 100 percent effective March 1, 2021 until December 31, 2021. The process for submitting a mortgage without a down payment is the same as the process for applying for a mortgage in general. In the process of applying for a mortgage, the developer will usually be assisted directly by a developer who has become a partner at BRI Singaraja Branch. After completing all the requirements, BRI Singaraja Branch will approve the mortgage application within one month. Within one month, the bank as the mortgage provider will conduct a survey process on several different parties. The survey process will examine all financial activities at Bank Indonesia to determine whether the customer is registered on a credit blacklist.

b) Home ownership loans (KPR) are considered to have managed to grow quite well after the tax exemption stimulus provided by the government and the loosening of loan to value (LTV) provided by Bank Indonesia (BI). Until the first half of 2021, Financial Ratios show that property loans are the support for bank loans. Even the rate of mortgage loans, which is projected to grow even higher by the end of the year compared to other credit sectors, even though mortgage interest rates have not fallen significantly.

c) The sustainability of BRI's performance is reflected in the LDR and CAR ratios which are at ideal numbers. BRI's LDR at the end of March 2021 was $87.12 \%$, while the CAR was $19.74 \%$ or an increase from the same period the previous year, which was 18.56\%." BRI Tbk Singaraja Branch Office in the first quarter of 2021.

Based on the results of the research and the conclusions that have been presented, suggestions that can be given to PT BRI Singaraja Branch and the development of further research are: a) PT BRI Singaraja Branch is advised to increase control in the implementation of the 0 Percent DP KPR Policy by conducting procedures and surveys on mortgage applications from customers, b) make improvements to educate the public in helping to plan credit, especially the type of mortgage so that the policy is right on target, c) Further research can be carried out in terms of the effectiveness of the 0 Percent DP KPR policy from the Customer who is affected by covid 19

\section{ACKNOWLEDGMENT}

This research process has been funded by the internal fund from Universitas Pendidikan Ganesha. Thank you to Rector of Universitas Pendidikan Ganesha for the funding that has been given. Mrs. Ni Luh Asri Savitri, and Mrs. Arie Wahyuni thank you for your endless support for this research. Thank you to all those who helped this research process. 


\section{REFERENCES}

[1] IMF, "World Economic Outlook, April 2020: The Great Lockdown," WORLD ECONOMIC OUTLOOK, 2020. https://www.imf.org/en/Publications/WEO/Issue s/2020/04/14/weo-april-2020.

[2] S. Fathurrahman, "Analisis Implementasi Dan Kebijakan Penyaluran Kredit Pemilikan Rumah (Kpr) Pada Consumer Loan Pt Bank X (Persero) Tbk Cabang Malang," Universitas Muhammadiyah Malang, 2020.

[3] F. Alanshari and D. Marlius, "Prosedur Pemberian Kredit KPR Pada PT. Bank Tabungan Negara (Persero) TBK Cabang Pembantu Bukittinggi," 2018.

[4] Z. A. Priliansyah, A. Rasyid, and K. Najib, "Kebijakan Pemerintah Dalam Pemberian Subsidi Perumahan Bagi Masyarakat Berpenghasilan Rendah (Studi Perumahan Mendalo Hill Kecamatan Jambi Luar Kota)," UIN Sulthan Thaha Saifuddin Jambi, 2021.

[5] S. Witdiyanto, M. Mukhlis, and A. Hidayat, "Analisis Determinan Penyaluran Kredit Pemilikan Rumah Di Indonesia Periode 20092019," Sriwijaya University, 2021.

[6] Sugiyono, Memahami Penelitian Kualitatif. Bandung: Alfabeta, 2012.

[7] Z. Azhar and M. Handayani, "Analisis faktor prioritas dalam pemilihan perumahan $\mathrm{kpr}$ menggunakan metode AHP," J. Manaj. Inform. dan Sist. Inf., vol. 1, no. 2, pp. 19-22, 2018. 